\title{
The Status Quo Characteristics and Innovative Research of Ideological and Political Education of Postgraduates at the Universities of Finance and Economics
}

\author{
Xinxin Zhang \\ School of Art and Design \\ Nanjing University of Finance and Economics \\ NUFE \\ Nanjing, China \\ 50410594@qq.com
}

\author{
Lei Jiao \\ Financial Department \\ Nanjing University of Finance and Economics \\ NUFE \\ Nanjing, China \\ 793861985@qq.com
}

\begin{abstract}
Postgraduates at universities of finance and economics are special in student sources, social experiences, subject nature and training purposes. This thesis focuses on their status quo and characteristics in ideological and political education. It aims to put forward suggestions to improve and advance the methods of their ideological and political education from three aspects, strengthening educational pertinence, improving postgraduates' abilities of service and teamwork, exerting synergy of all-round education at universities.
\end{abstract}

Keywords-universities of finance and economics; postgraduates; ideological and political education; synergy at universities

\section{INTRODUCTION}

With the rapid economic development in China, there's an increasing demand for high-level talents in the field of finance and economics, so the student enrollment of this major has naturally increased in recent years. However, with the enlarging scale of postgraduates, more and more negative news such as "academic misconduct" "suicide out of too much pressure" are often seen in the newspaper. As more attention is paid to the well-educated, there's a new topic raised for universities-under the increasing challenging situations at home and abroad, complicated social environment and pluralistic values, it is a social responsibility and historical mission shouldered by teachers at universities about how to guide postgraduates to set up correct ideas, active values and positive attitudes, which is deeply related to whether qualified successors can be cultivated to assume the task of national rejuvenation for the new era.

Postgraduates differ with undergraduates in age, major backgrounds, training methods and vocational types, while postgraduates from universities of finance and economics are more special in student sources, social experience, subject nature and training purposes. Therefore, in the ideological and

The work described in this paper was fully supported by the University Philosophy and Social Sciences Research Funding of Jiangsu Province "Research on practice and innovation of Ideological and political work at Universities of Finance and Economics in the context of" micro era "(Project No.: 2017SJBFDY336) political education for postgraduates at universities of finance and economics, the levels and differences of educational objectives should be stressed so as to have a definite object in view and feasibly improve the efficiency of ideological and political education.

II. THE DILEMMA AND CAUSES OF IDEOLOGICAL AND POLITICAL WORK FOR POSTGRADUATES AT UNIVERSITIES OF FINANCE AND ECONOMICS

\section{A. Complicated student sources and pluralistic educational objectives}

Disciplines of finance and management are the support among that of universities of finance and economics. Apart from relatively high professional quality, postgraduates majoring in finance and management also need a few practical experiences in their research field, thus there being a large proportion of students with related working experiences among enrolled students. In addition to full-time postgraduates, some universities of finance and economics also recruit part-time postgraduates. Meanwhile, the phenomenon of interdisciplinary postgraduate entrance examination is very common, which causes disparity of postgraduates in age, vocational backgrounds, social experiences and professional basis. Some of them have formed relatively stable outlooks on the world, life and values, unwilling to passively receive curriculum education and theme activities and thus ignoring further study and improvement in this field.

\section{B. Stressing scientific research and neglecting moral} education, calling for improvement in social responsibility

Compared with undergraduates, postgraduates majoring in finance and management are more mature in learning ability and personality independence. Due to independent learning, they often neglect teamwork and have a weak sense of team spirit. They would rather communicate with their tutors personally than conduct teamwork with their partners. The author has discovered from the practical work that the 
meeting the requirements of ideological and political education for such students. doing researches and writing papers as their main tasks are obviously insufficient, and the enthusiasm of participating in League branch and Party branch and other organizations at all levels significantly decline. This phenomenon of stressing academic research but neglecting social practice is very common to see in universities. In their practical work after graduation, these postgraduates will eventually expose their lack of abilities in interpersonal communication, team cooperation, organization and coordination, which restricts their long-term development.

Aside from a small fraction of students with working experiences, the majority of full-time students at universities are mostly "post 1995" generation who are active in mind, keener to new things as well as have more open and diverse values. They are direct in expressing self-need psychologically and desperate to realize their life goals, which requires a high demand for the difficulty in education and the renewal of knowledge to ideological and political teachers.

\section{Not having made joint efforts in the ideological and political education of postgraduates, requiring advance in education quality}

From "enhancing morality and then fostering talents" we can see that the most important is to enhance morality. As the key work of universities of finance and economics, ideological and political work is not isolated, and rather it should be taken as a central work integrated into school education and play a leading role. On the one hand, universities of finance and economics take some measures in management system construction, the quality improvement of ideology and politics as the 1st class, extension effect of the 2nd class and faculty members' construction. But most of these measures regard undergraduates and postgraduates as an object of education without focusing on the inherent characteristics of postgraduates. In examining and appraising the performances of postgraduates, attention is always paid to teaching processes and scientific researches, such as curriculum achievements, scientific research quality, graduation thesis and other indicators. The requirements for the quality and effect of ideological and political education for postgraduates are relatively broad. On the other hand, in terms of the construction of ideological and political team work, the guidance of tutors to students mainly focuses on professional research, instead of concerning and grasping students' ideological trends. Naturally, their ideological education is limited to ideological and political theory classes and daily management from their counselors.

As a result, in the aspects of the relationship between the ideological and political education of postgraduates and other work, the construction of environment, the test standard of the effectiveness of ideological and political work and the construction of the work team, universities of finance and economics lack linkage initiatives targeted to the efficiency and improvement of this kind education. This requires the ideological and political teachers to grasp and analyze the characteristics of educational objects with the times and explore a more suitable form of work for postgraduates,

\section{THE INNOVATION AND CONSIDERATION OF \\ IDEOLOGICAL AND POLITICAL EDUCATION FOR \\ POSTGRADUATES FROM UNIVERSITIES OF FINANCE AND ECONOMICS}

\section{A. Grasping the characteristics of postgraduates majoring in finance and economics, strengthening the validity of ideological and political education}

General Secretary Xi Jinping pointed out at the national conference on the ideological and political work of colleges and universities: "Fundamentally, ideological and political work is people-centered, which must focus on, care for and serve students, increasing their ideological level, political consciousness, moral quality and cultural literacy as well as training virtuous talents with all-round development.”.[1] This important assertion gives us two inspirations. One is that ideological and political work must be student-centered, distinguish students' characteristics and levels of physical and mental development and keep pace with the times. The other is that the final goal of training talents in colleges and universities is to get equal stress on integrity and ability. The subjects of postgraduates' education are relatively well-educated, and tutors together with counselors who are engaged in postgraduate education have high level of political theory and professional quality. However, compared with undergraduates, postgraduates have pluralistic characteristics in age, social experience and psychological maturity as the like, which requires education subjects to give more targeted classes in a timelier manner.

During the past years, with the increasing employment pressure in the society, most students' motives for a master's degree is changed from further study in major and academy to "evasion"-escaping employment, competition and society. There are certainly some influences from the society, but the motives of most students to attend the postgraduate exam also determine their hidden psychological pitfalls in their postgraduate period. The pitfalls are ambiguous goals, weak tolerance in case of setbacks and self-positioning imbalance, etc. Different from undergraduates, the number of postgraduates in each class and each major is relatively small, so that their tutors, teachers and counselors have more time and energy to care for students.

\section{B. Guided by majors and current affairs, enhancing the social service ability and team cooperation ability of postgraduates}

The ideological and political work members need to ceaselessly strengthen their theory learning and improve their ability of teaching ability and updating knowledge so as to adjust the constant changes in a major development, social environment and educational objectives. It is necessary to know that postgraduates at universities of finance and economics tend to attach more importance to socioeconomic hot issues due to their subject attributes. Consequently, it is a significant topic that how to guide them to form correct understanding and ideology on such issues in the process of 
teaching guidance and daily communication. For example, the trade friction between China and the United States as one of the social hot issues has aroused great attention among teachers and students. Especially for postgraduates majoring in International Economy, International Trade, Western Economics and Political Economics, they are more likely to carry out deep discussions and analyses from their research direction. But the prerequisite of discussing and analyzing problems is to bear in mind the identity of postgraduates in the new era and the missions one should take. Thus, teachers should exactly understand the ins and outs of the trade friction between China and the United States, our country's overall policy and specific strategies and the current situation change. In their discussions and analyses, teachers are supposed to guide students to have confidence and firm patriotism, integrate thoughts and deeds into national decisions and encourage students' enthusiasm for the study and research of their majors.

Postgraduates at universities of finance and economics still have some salient problems. First, the relationship between research topics and practices is not close enough, causing the research results to fail to serve for social-economic development. Second, the research method is single because their information is mostly from the internet instead of field research. Third, they are so independent that they tend to dominate their researches on their own and lack the consciousness of team cooperation. These factors, to a great extent, restrict the practicability and innovation of their research results as well as their own ability in scientific comprehensive development. When tutors, teachers and counselors guide postgraduates to conduct major researches, they should concern the following respects. Firstly, students should emphasize that theories must be connected with practices, making clear that scientific studies must be combined with serving economic construction, giving full play to their strengths and carrying out researches based on the need for regional social and economic development. Secondly, students, especially professional postgraduates, need to participate in more social practices, doing surveys and researches in businesses, scientific institutes and rural areas to provide valuable research results for the regional economic construction. Meanwhile, when postgraduates get information from the Internet, special attention should be paid to screen the mixed negative information. They need to improve judgment to avoid blind faith and credulity. Ideological and political teachers also should communicate with students more and provide timely guidance and assistance once finding students are infringed by harmful information. Thirdly, students should be encouraged to voluntarily form teams with like-minded ones and make joint efforts, allowing full play to team advantages so as to provide intellectual support for undertaking and completing more challenging scientific researches. Likewise, teamwork will inspire students to go out of their dormitories, improve their interpersonal communication ability and lay a solid foundation for their future careers.

\section{Giving full play to the synergistic effect of all-round education on campus, making a concerted effort in ideological and political education}

Universities of finance and economics should strengthen intramural management of ideological and political education, building an effective mechanism of it. Extra efforts should be made in leadership management, system guarantee and implementation to promote and advance ideological and political work. At the same time, under the new tasks and requirements of the new situation, media convergence can be employed to make the ideal and belief education and the socialist core values education enter students' classes and their minds. In order to exert synergistic effect of all-round education on campus, work can be done from the following two aspects:

The first one is that all departments and colleges should cooperate with each other and fully realize the importance and urgency of ideological and political work.[2]Having both virtues and ability is the ultimate goal of talent training at colleges and universities. The moral education should run through each part of postgraduates training. On the basis of obeying education rules, teachers can make the most of the attributes of majors like finance and economics and management to conduct studies from History, Sociology and Political Economics. Thus, students' moral judgment and consciousness of choice will be enhanced, the experience and understanding of major culture and spirit tradition elevated, profound patriotic belief cultivated, national pride and selfconfidence built. [3]At present, among the evaluation indexes of the quality of postgraduate training at universities of finance and economics, these factors play an important role-the quality of student sources, subject construction, scientific research findings, international communication and employment levels. It can be found that the evaluation of ideological and political work is not considered as one of these indexes. The relevant requirements in National Evaluation System of Ideological and Political Education for College Students (Trial) issued by the Ministry of Education should be fully implemented, promoting institutionalized and scientific development in ideological and political education.

The second one is to create a work team dominated by tutors and assisted by counselors.

On one thing, tutors whose virtues and charisma have a profound effect on postgraduates, have the closest connection with them during their academic life. Therefore, tutors' guidance to postgraduates should not be limited to the improvement of professional knowledge and scientific researches.[4]What's more, tutors have to strengthen ideological guidance in cultivating their academic ability and give oriented instructions. List some examples. Remain academic integrity in scientific researches, develop team spirit in cooperation and stick to the down-to-earth attitude. These all need the influences and guidance from a tutor.

On another, counselors of postgraduates also take a significant role in ideological and political work, resolving their various problems before graduation. Usually, counselors are equipped with relatively rich working experience, but postgraduates at universities of finance and economics are 
economics. In order to propose suggestions, three aspects are

students who are in-service or have had working experiences so that their social experience and backgrounds have certain complexity and their outlooks are basically stereotyped. Consequently, counselors need to pay special attention to education methods, avoiding traditional indoctrination. On the contrary, counselors should offer concern and guidance duly to students in an acceptable way, tracking, supporting and instructing students' state of mind, value orientation, daily life and employment, etc. Since 1995, part of PhD students and master students with good political quality and excellent working ability at Tsinghua University are selected to shoulder the position of postgraduates' moral education assistant and take charge of Party construction and ideological and economical work of postgraduates for a part-time job. [5]This is beneficial to penetrate ideological and political education into daily life, strengthen its affinity and improve education effect. There is no doubt that this can be regarded as a new idea for ideological and political work team construction that can be referred to at universities of finance and economics.

As General Secretary Xi Jinping stresses, the ideal and belief, mental state and comprehensive quality of the young generations are not only a significant embodiment of a country's vitality but also an important factor of a country's core competitiveness. [6] This thesis is based on grasping the status quo and characteristics in the ideological and political education of postgraduates from universities of finance and researched-strengthening educational pertinence, improving postgraduates' abilities of service and teamwork, exerting synergy of all-round education at universities. It is expected to increase the quality and effect of their ideological and political education which is also a common mission and responsibility for each educator.

\section{REFERENCES}

[1] XI JINPING THE GOVERNANCE OF CHINA II . Beijing: Foreign Languages Press, 2017

[2] Feng Gang. Annual release of research hotspot of Ideological and political education. Unity Press, 2019. (In Chinese)

[3] He Weiwei. Research on Moral Education Problems and Countermeasures at Colleges and Universities of Economics and Management. Inheritance \& Innovation, 2011, 6: 1-3. (In Chinese)

[4] Shan Chunxiao. A new perspective of Ideological and political education in colleges and universities. Beijing: People's Publishing House, 2011. (In Chinese)

[5] Zhang Shujun. Important theoretical exploration of discipline: my 18 insights on Ideological and Political Education. China Renmin University Press, 2018. (In Chinese)

[6] Speech of Xi Jinping at the China University of Political Science and Law, 2017. Retrieved on Nov.7, 2019 from http://www.xinhuanet.com//politics/2017-05/03/c_1120913310.htm. 